\title{
Multiple origins and chromosomal novelty in the allotetraploid Tragopogon castellanus (Asteraceae)
}

\section{Evgeny V. Mavrodiev ${ }^{1}$, Michael Chester ${ }^{1,2}$, Víctor N. Suárez-Santiago ${ }^{3}$, Clayton J. Visger ${ }^{1,2}$, Roseana Rodriguez ${ }^{2}$, Alfonso Susanna ${ }^{4}$, Riccardo M. Baldini ${ }^{5}$, Pamela S. Soltis ${ }^{1}$ and Douglas E. Soltis ${ }^{1,2}$}

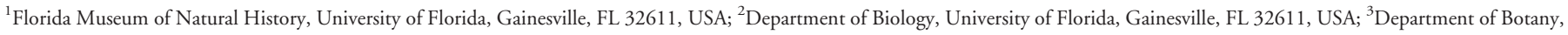

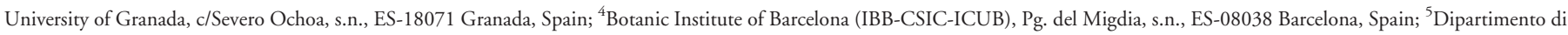

Biologia \& Centro Studi Erbario Tropicale, Università degli Studi, Via G. La Pira 4, I-50121 Firenze, Italy

Author for correspondence:

Evgeny V. Mavrodiev

Tel: +352 2731961

Email: evgeny@ufl.edu

Received: 6 April 2014

Accepted: 10 November 2014

New Phytologist (2015)

doi: 10.1111/nph.13227

Key words: allopolyploidy, chromosomal translocations, cryptic species, Iberian Peninsula, recurrent formation, Tragopogon.

\section{Summary}

- Tragopogon includes two classic examples of recently formed allopolyploid species in North America: T. mirus and T. miscellus. Older Tragopogon allotetraploids from Eurasia offer ideal taxa for comparing the longer term outcomes of allopolyploidy.

- To help resolve the ancestry of one of these older polyploids, phylogenetic analyses of multiple populations of the allotetraploid $T$. castellanus $(2 n=24)$ and its putative diploid parents, T. crocifolius and T. lamottei, were conducted using sequences from nuclear (internal transcribed spacer, ITS; and alcohol dehydrogenase 1A, Adh) and plastid (trnT-trnL spacer, trnL intron, trnL-trnF spacer and rp/16 intron) loci. Fluorescence in situ hybridization (FISH) and genomic in situ hybridization (GISH) were used to investigate the chromosomal constitution of $T$. castellanus.

- Our data confirm that the widely distributed T. crocifolius and the Iberian endemic, $T$. lamottei, are the diploid parents of $T$. castellanus, and that this polyploid formed at least three times.

- One group of populations of $T$. castellanus is distinct in exhibiting two pairs of rearranged chromosomes. These data suggest that some of the chromosomal variants that originate in young polyploids (here, an intergenomic translocation) may become fixed in populations, contributing to novelty in older polyploid lineages. The geographical distributions of the allopolyploids and parents are also complex, with allotetraploid populations being disjunct from one or both of the most closely related diploid parental populations.

\section{Introduction}

Tragopogon L. has emerged as a model system for the study of recent polyploidy in natural populations. Intensive study of the New World neoallotetraploids T. mirus Ownbey and T. miscellus Ownbey has revealed rapid chromosomal and genomic changecatching evolution in the act (Soltis et al., 2012). Losses of homeologs (genes duplicated by polyploidy) and the origins of chromosomal variants (translocations, compensated aneuploidy) in these young allotetraploids have produced arrays of novel genotypes. But what is the fate of the homeolog loss and chromosomal changes observed in these young polyploids after several thousand or more generations? To fill this gap in our understanding of the evolutionary significance of this extensive genetic and chromosomal polymorphism in new polyploids, studies of related and older polyploids are needed.

Dedicated to the memory of Francis Marion Ownbey (1910-1974), Sergei Vasilievich Juzepczuk (1893-1959) and Anton Joseph Kerner Ritter von Marilaun (1831-1898).
Four endemic polyploid taxa of Tragopogon are known from Spain and nearby Morocco (Vogt \& Oberprieler, 1993; Blanca \& Diaz De La Guardia, 1996; Diaz De La Guardia \& Blanca, 2004). Here, using genetic and chromosomal data and building on previous results (Mavrodiev et al., 2008), we investigate the ancestry and history of one of them, T. castellanus Lereshe \& Levier.

Tragopogon castellanus, distributed in the northern half of the Iberian Peninsula (Blanca \& Diaz De La Guardia, 1996), was described $>125 \mathrm{yr}$ ago (in Leresche \& Levier, 1881), but was documented as a tetraploid $(2 n=24)$ only $30 \mathrm{yr}$ ago (Wilson, 1983). On the basis of morphology and cytology, Wilson (1983) suggested that the diploid T. crocifolius L. $(2 n=12)$ could be one parent of $T$. castellanus. On the basis of morphology and internal transcribed spacer (ITS), external transcribed spacer (ETS) and plastid sequence data, T.crocifolius and T.lamottei Rouy $(2 n=12)$ were proposed as putative parents of T. castellanus (Mavrodiev et al., 2008), although sampling of all three species was limited. 
As a result of its morphological similarity to T.crocifolius, T. castellanus has sometimes been considered as a synonym (e.g. Richardson, 1976) or a subspecies (T. crocifolius ssp. badalii Willk.; Willkomm, 1893; see also Diaz De La Guardia \& Blanca, 1990) of this taxon; however, these species have been treated as distinct in more recent studies (e.g. Wilson, 1983; Diaz De La Guardia \& Blanca, 1990, 1992; Blanca \& Diaz De La Guardia, 1996), but with the inclusion of T. crocifolius ssp. badalii in T. castellanus (Diaz De La Guardia \& Blanca, 1990). Tragopogon crocifolius is thought to occur throughout the Mediterranean area (Wilson, 1983; Vogt \& Oberprieler, 1993), as well as in Central and Northern Europe (Richardson, 1976; Wilson, 1983). However, up to seven species have been previously circumscribed from 'T.crocifolius', and the taxon is polyphyletic (Mavrodiev et al., 2008, 2012). Only a single collection of T. crocifolius has been reported from southwestern Spain (see Blanca \& Diaz De La Guardia, 1996), from an area in which T. castellanus was not previously found (e.g. Blanca \& Diaz De La Guardia, 1996). It is not clear which lineage of T. crocifolius occurs in the Iberian Peninsula - including those related to the putative parent of T. castellanus. Tragopogon lamottei is an Iberian endemic, rediscovered in Spain c. $25 \mathrm{yr}$ ago and found primarily in the northern part of the peninsula (Diaz De La Guardia \& Blanca, 1988; Blanca \& Diaz De La Guardia, 1996).

To test further the proposed parentage of T. castellanus, to assess the number of polyploid origins and to characterize the extent of genetic and chromosomal diversity in this allotetraploid, we analysed multiple populations of T. castellanus and its proposed parents using DNA sequence data and molecular cytogenetic methods (genomic in situ hybridization, GISH; and fluorescence in situ hybridization, FISH).

\section{Materials and Methods}

\section{Sampling}

This study included two rounds of field collecting (Supporting Information Table S1): the first was performed in 2006 by V. N. Suárez-Santiago and the second by D. E. and P. S. Soltis, V. N. Suárez-Santiago and A. Susanna during the summer of 2012. At least two localities of T. lamottei and three of T.castellanus (including the locus classicus of the species, population 3029) were sampled twice (in both 2006 and 2012) (Table S1). We also analysed three samples of T. crocifolius collected in Sicily by R. M. Baldini in 2012 (Table S1), and additionally 12 herbarium specimens collected in Italy and deposited in the Museum of Natural History, University of Florence (Florence, Italy, FI), the Herbarium of the Royal Botanic Garden of Madrid (Madrid, Spain, $\mathrm{MA}$ ), the Herbarium of the University of Rome (La Sapienza, $\mathrm{RO})$ and the Herbarium of the Botanical Institute in Bari, Italy (BI) (Supporting Information Notes S1). Dry leaf tissues were obtained from BI, FI, MA and RO by R. M. Baldini during 2007-2009, together with high-quality images of specimens, whenever possible.

In all, 99 individuals from 59 local populations were analysed: T. castellanus, 32 populations; T. lamottei, 14 populations;
T. crocifolius, 13 populations (Tables S1, S2; Notes S1). The GPS coordinates assigned for most populations investigated in Spain are given in Table S1. In many cases, T. lamottei and T. castellanus occurred at the same locality, and therefore share GPS coordinates, but have different population numbers (Table S1).

Specimen vouchers for the populations listed in Table $S 1$ are deposited at the University of Florida and University of Granada Herbaria (FLAS, GDA).

\section{Chromosome counts}

For selected individuals representing populations of T. lamottei and T. castellanus sampled in Spain before 2012, chromosomes were counted at metaphase in root-tip meristem cells taken from germinating seeds. Roots were pretreated with 8-hydroxyquinoline, fixed in ethanol-acetic acid (3:1), hydrolysed in $1 \mathrm{M} \mathrm{HCl}$, stained in acetic orcein solution and then flattened for light microscopy (Darlington \& La Cour, 1969).

\section{Flow cytometry}

The ploidy of silica-dried leaf material collected in the field during 2012 was determined using a modified version of the bead beating method described in Roberts et al. (2009). Samples were processed in batches of 24 . For each sample, $5 \mathrm{mg}$ of dried Tragopogon leaf material and $2 \mathrm{mg}$ of dried Brassica oleracea leaf material (as a standard) were placed in a 1.5-ml Eppendorf tube containing two zirconia beads and agitated in a bead mill for $2-$ $3 \mathrm{~s}$. After milling, $500 \mu \mathrm{l}$ of cold lysis buffer $(0.1 \mathrm{M}$ citric acid, $0.5 \% \mathrm{v} / \mathrm{v}$ Triton X-100, 1\% w/v PVP-40 (polyvinylpyrrolidone, average molecular weight 40 000)) (Yokoya et al., 2000; Hanson et al., 2005) were added to each sample. After $5 \mathrm{~min}$ of incubation on ice and intermittent gentle mixing by hand, each sample was filtered using a $5-\mathrm{ml}$ polystyrene round-bottomed tube with a cell-strainer cap (BD Falcon; Becton Dickinson \& Co., Franklin Lakes, NJ, USA). A 140- $\mu$ l aliquot of filtrate was placed in a new 1.5-ml Eppendorf tube with $1 \mu \mathrm{l}$ of $\mathrm{RNaseA}\left(1 \mathrm{mg} \mathrm{ml}^{-1}\right)$ (Thermo Scientific Molecular Biology, Fisher Scientific, Pittsburgh, PA, USA) and incubated at $37^{\circ} \mathrm{C}$ for $20 \mathrm{~min}$. Next, $350 \mu \mathrm{l}$ of propidium iodide (PI) staining solution $(0.4 \mathrm{M}$ $\mathrm{NaPO}_{4}, 10 \mathrm{mM}$ sodium citrate, $25 \mathrm{mM}$ sodium sulfate, $50 \mu \mathrm{g} \mathrm{ml}^{-1}$ PI) were added to each tube of nuclei suspension. After $1 \mathrm{~h}$ at room temperature, stained nuclei suspensions were run at $14 \mu \mathrm{min}^{-1}$ on an Accuri C6 flow cytometer (BD Biosciences, San Jose, CA, USA) fitted with a 488-nm laser. Fluorescence measurements were made using the FL2 $(585 / 40 \mathrm{~nm})$ optical filter, capturing 10000 events and utilizing the FL2-A values for the $2 \mathrm{C}$ peak.

\section{Cultivation of plants for GISH and FISH analysis}

Plants were grown from field-collected seed to provide root tips for FISH and GISH analysis. Seeds from two to five maternal individuals per population were selected. Germination was carried out by washing seeds in $8 \%$ domestic bleach, rinsing in distilled water and placing them in Petri dishes lined with paper 
towels moistened with distilled water. Seeds on plates were cold treated at $4{ }^{\circ} \mathrm{C}$ in the dark for $3 \mathrm{~d}$, and then moved to a bench top close to a window to provide light. Following germination, young plants were grown in a temperature-controlled glasshouse at the University of Florida. Plants were grown in $12.7 \mathrm{~cm}$ pots in a mixture of Fafard 52 Mix (Hummert International, Earth City, MO, USA), Quikrete Premium Play Sand (Lowes, Gainesville, FL, USA) and Turface All Sport Granules (John Deere Landscapes, Gainesville, FL, USA).

\section{Fluorescence and genomic in situ hybridization}

The terminal $2 \mathrm{~cm}$ of growing roots were harvested and pretreated in an aqueous solution of $2 \mathrm{mM}$ 8-hydroxyquinoline for $16 \mathrm{~h}$ at $4^{\circ} \mathrm{C}$. Pretreated roots were then fixed in ice-cold $90 \%$ acetic acid for $10 \mathrm{~min}$ and transferred to $70 \%$ ethanol for $-20^{\circ} \mathrm{C}$ storage, as described by Kato et al. (2011). Mitotic chromosome preparations followed Kato et al. (2011) using $28 \mu \mathrm{l}$ of glacial acetic acid for the suspension of digested cells.

DNA probes were made for GISH from total genomic DNA of one individual of T. crocifolius and one of T. lamottei. DNAs were isolated using a cetyltrimethylammonium bromide (CTAB) method (Doyle \& Doyle, 1987) and treated with RNase. For FISH, probe templates comprised a cloned 1.3-kbp $18 \mathrm{~S}$ rDNA fragment from T. dubius Scop., and complementary oligonucleotides were annealed to make double-stranded DNA (dsDNA) for the centromeric repeat, TPRMBO (Pires et al., 2004), the subtelomeric repeat, TGP7 (Pires et al., 2004), and the interstitial repeat, TTR3 (Chester et al., 2013). We followed the methods of Kato et al. (2011) for the labelling of DNA probes by nick translation, using $5 \mu \mathrm{g}$ of dsDNA as substrate (for details, see Chester et al., 2013). Probes were directly labelled by incorporating one of the following: fluorescein-12-dUTP, cyanine 3-dUTP or cyanine 5-dUTP (Perkin Elmer Inc., Waltham, MA, USA). Nick translation products were purified using a QIAquick Nucleotide Removal Kit (Qiagen Inc., Valencia, CA, USA).

FISH and GISH were conducted following Kato et al. (2011). The FISH mixture comprised 350 ng of Cy5-labelled TPRMBO probe, $180 \mathrm{ng}$ of Cy3-labelled TGP7 probe, $300 \mathrm{ng}$ of fluorescein-labelled TTR3 probe, $20 \mathrm{ng}$ of Cy3-labelled 18S rDNA probe, $20 \mathrm{ng}$ of fluorescein-labelled $18 \mathrm{~S} \mathrm{rDNA}$ probe and $700 \mathrm{ng}$ of unlabelled sheared salmon sperm DNA in $0.7 \times$ SSC $(300 \mathrm{mM} \mathrm{NaCl}, 30 \mathrm{mM}$ sodium citrate; pH 7.0). The GISH mixture comprised $400 \mathrm{ng}$ of fluorescein-labelled T.crocifolius gDNA, $400 \mathrm{ng}$ of Cy3-labelled T. lamottei gDNA and $560 \mathrm{ng}$ of sheared salmon sperm DNA in $0.7 \times$ SSC. Before in situ hybridization, slides were UV crosslinked $\left(120 \mathrm{~mJ} \mathrm{~cm}^{-2}\right)$; the hybridization mixture was then added to the slide, and a coverslip was placed on top. Slides containing the probe mixtures were denatured at $82-83^{\circ} \mathrm{C}$ for $2 \mathrm{~min} 30 \mathrm{~s}$ and transferred to a sealed humid box for incubation at $55^{\circ} \mathrm{C}$ for $16 \mathrm{~h}$ for FISH, or $36 \mathrm{~h}$ for GISH. Following hybridization, slides were washed briefly in $2 \times$ SSC to remove coverslips. Glass coverslips (Corning Inc., Corning, NY, USA) were then mounted using Vectashield containing 4',6-diamidino-2-phenylindole dihydrochloride (DAPI) (Vector Laboratories Inc., Burlingame, CA, USA). Hybridized chromosome spreads were observed and imaged using a Zeiss Axio Imager.M2 fluorescence microscope (Carl Zeiss MicroImaging Inc., Thornwood, NY, USA) with an X-Cite Series 120 Q Lamp (Lumen Dynamics Group Inc., Mississauga, ON, Canada). The brightness and contrast of the captured images were adjusted in AxioVision (version 4.8 Special Edition 64 bit, Carl Zeiss MicroImaging, Inc.) by moving the upper and lower cutoffs in the histogram of signal intensity.

GISH reprobing of FISH-probed slides used the GISH method described above after removing the glass coverslips in $2 \times$ SSC. Karyotypes based on FISH and/or GISH were assembled in Photoshop CS3 (Adobe Systems Inc., San Jose, CA, USA) using the merged and coloured TIFF images exported from AxioVision. Chromosome designations A-F for T. lamottei and T. crocifolius were based on FISH signal distributions (TPRMBO, TGP7, TTR3, TTR15 and 18S rDNA) previously documented for $T$. pratensis $\mathrm{L}$. and T. dubius, respectively (Chester et al., 2013).

\section{Amplification, cloning and sequencing}

We amplified and sequenced the following DNA regions: two nuclear loci (ITS, alcohol dehydrogenase 1A, $A d h$ ) and four plastid loci (trnT-trnL spacer, $\operatorname{trn} L$ intron, $\operatorname{trn} L$-trnF spacer (all three regions amplified and sequenced as one unit) and the rpl16 intron). The strategy of amplification and cloning generally followed that described in Mavrodiev etal. (2008, 2012), but the number of PCR cycles was decreased from 25-40 to 15 in the case of $A d h$ to suppress artefactual recombination events arising during PCR between Adh parental copies in T. castellanus. ITS copies of T. lamottei were previously recovered from individuals of $T$. castellanus in very low numbers by sequencing a large number of clones (Mavrodiev etal., 2008; V. N. Suárez-Santiago etal., unpublished). Because the FISH data show that the T. lamottei $35 \mathrm{~S}$ rDNA contribution has been substantially reduced in all individuals of $T$. castellanus examined (see below), ITS was not cloned in this study for T. castellanus. Four plastid regions (trnT-trnL spacer, trnL intron, trnL-trnF spacer and $r p l 16$ intron) were sequenced, concatenated and analysed as a single contiguous dataset.

\section{Phylogenetic analyses}

Maximum likelihood (ML) analyses of the ITS, $A d h$ and plastid datasets were conducted separately using RAxML (Stamatakis, 2014) following the strategy described in Mavrodiev et al. (2008, 2012) using sequence data from Mavrodiev et al. (2008) (plastid sequences) and Mavrodiev et al. (2012) (ITS and Adh sequences), with the addition of new sequences for samples of $T$. castellanus, T. crocifolius and T. lamottei. The ITS matrix included sequence data for most species of Tragopogon (Mavrodiev et al., 2012).

For ITS, only direct ('raw') sequences were included in the analyses (as noted above, cloning was conducted earlier for T. castellanus). For Adh, both direct sequences (from T. lamottei) and clones (from T.crocifolius, T. castellanus and T. lamottei) were included in the analyses (individuals were selected based on 
the analyses of ITS and plastid sequence data; for the individuals cloned, see Table S1). For cloned samples, single nucleotide polymorphisms (SNPs) observed in single clones were excluded as possible artefacts of amplification and/or sequencing following Mavrodiev et al. (2012).

\section{Results}

\section{Ploidy}

Ploidy was estimated via flow cytometry of field-collected or dried leaf tissues, or by chromosome counts of plants grown from seed (Table S1). Of the 99 individuals sampled, ploidy was obtained for almost all recently collected samples (77 of 87). Chromosomes were counted for 28 individual plants. We consistently found T.castellanus to be tetraploid with counts of $2 n=4 x=24$, and all T. lamottei and T. crocifolius to be diploid with counts of $2 n=2 x=12$.

\section{ITS sequences}

The total number of positions in the ITS alignment was $727 ; 13$ SNPs and two single nucleotide insertions/deletions differentiated T. crocifolius and T. lamottei (Table S2). Populations of T. lamottei had one of two ITS variants that differed by a single SNP (157) (Table S2). These two variants formed a clade $(86 \%$ ML bootstrap (BS)) that was sister to T. porrifolius ssp. porrifolius (58\% ML BS) (Fig. 1c), in agreement with previous results (e.g. Mavrodiev et al., 2008).

All T. castellanus individuals had identical ITS sequences. Tragopogon castellanus was sister to samples of $T$. crocifolius from central Italy (Lazio, Pescara) (1065A, 1071A), southern Italy (park La Sila, Calabria) (1096A) and Sicily (3606, 3608 and 3609) (72\% ML BS) (Fig. 1b). These T. crocifolius sequences differed from the ITS sequences of T. castellanus at only two positions $(558,614)$ (Tables S2, S5). None of the ITS sequences of nine additional collections of T. crocifolius (Notes S1; Table S5) appeared to be as closely related to the ITS sequences of T. castellanus (Supporting Information Fig. S2).

\section{Plastid sequences}

The ML tree based on four plastid regions ( $\operatorname{trn} T$-trnL spacer, $\operatorname{trn} L$ intron, $\operatorname{trn} L-\operatorname{trn} F$ spacer and rpl16 intron) was largely unresolved (data not shown), but visual comparison of insertions and deletions, together with nucleotide substitutions of T. castellanus, T.crocifolius and T. lamottei, was informative for resolving the parentage of T. castellanus (for a summary, see Table S3). In the rpl16 intron, T. crocifolius and T. lamottei were differentiated by two or three indels and from zero to five SNPs (Table S3). Tragopogon lamottei individuals fell into one of two major haplotype groups (see later). With one exception, the sequences of T. castellanus were identical, or very similar to, the plastid sequences of T. lamottei, and most of the T. castellanus individuals could therefore be placed in one of the two T.lamottei haplotype groups. The T.lamottei-1 and
T. lamottei-2 haplotype groups differed by five SNPs (positions $58,61,62,65$ and 715) and a 6-bp deletion (869-874) (Table S3).

The T. lamottei-1 group comprised 18 T. lamottei individuals and 24 T. castellanus individuals (Table S1), all with identical sequences. The T. lamottei-1 haplotype differed from T. crocifolius (3606, 3608, 3609) by two indels (171-189 and 869-874 bp). The T. lamottei-2 group comprised 35 T. castellanus individuals and five T. lamottei individuals (Table S3). Four individuals of T. lamottei from the T. lamottei-2 haplotype group differed from the other T. lamottei-2 individuals by indels at positions 248-253, 852-864 and 597, and by an SNP at position 715. These results therefore further differentiated T. lamottei-2 into subgroups T. lamottei-2a and T. lamottei-2b (Table S3).

Haplotype group C, referred later as a separate origin, comprised a single individual of T. castellanus (population CASTMON) and several samples of $T$. crocifolius $(3606,3608,3609)$ (Table S1). In the rpl16 intron, the plants of haplotype C differed from T. lamottei by two or three indels and from zero to five SNPs (Table S3).

The other plastid regions were less informative. Within the trnL intron, a single SNP (position 345) was present. This was an A in T.crocifolius $(3606,3608,3609)$ and individuals of T. lamottei and T.castellanus from the T.lamottei-1 group, whereas individuals of T. castellanus and T. lamottei from the T. lamottei-2 group had a T. One T. lamottei individual (3569, population 3031) from the T. lamottei-2 haplotype group differed from all other individuals by a 10-bp insertion (positions 1120-1130) in the trnL-trnF spacer.

\section{Adh sequences}

We sequenced c. $850 \mathrm{bp}$ of the $A d h$ gene spanning four introns and four exons, sampling individuals to capture all of the variation uncovered by ITS and plastid sequencing, and the variation uncovered by karyotyping (see later). For $A d h$ sequencing, sampling comprised one individual of T. crocifolius (3606), 12 individuals of T. lamottei (including individuals from haplotype groups T. lamottei-1 and T. lamottei-2) and 13 individuals of T. castellanus (including individuals from haplotype groups T. lamottei-1 and T. lamottei-2) (Table S1).

For T. lamottei, direct sequencing of 10 individuals and cloning of two individuals recovered identical $A d h$ sequences (Table S4). Only a single sequence type was recovered from the diploid individual of T.crocifolius (Table S4; Fig. S1). The $A d h$ sequences of $T$.crocifolius and T.lamottei differed from each other by 29 or 30 SNPs and four or five indels (Table S4).

Across all accessions of $T$. castellanus, two distinct $A d h$ sequence types were consistently recovered, with one being T. crocifolius-like and the other being T. lamottei-like. The T. crocifolius-like $A d h$ copy obtained from T. castellanus differed from the $A d h$ sequence of diploid T. crocifolius at only a single site (450) (Table S4). The T. lamottei-like Adh copies of T. castellanus (variants I and II, Table S4) differed from the Adh sequences of T. lamottei by an SNP at position 200 and a 6-bp 
Adh (ML)

(a)

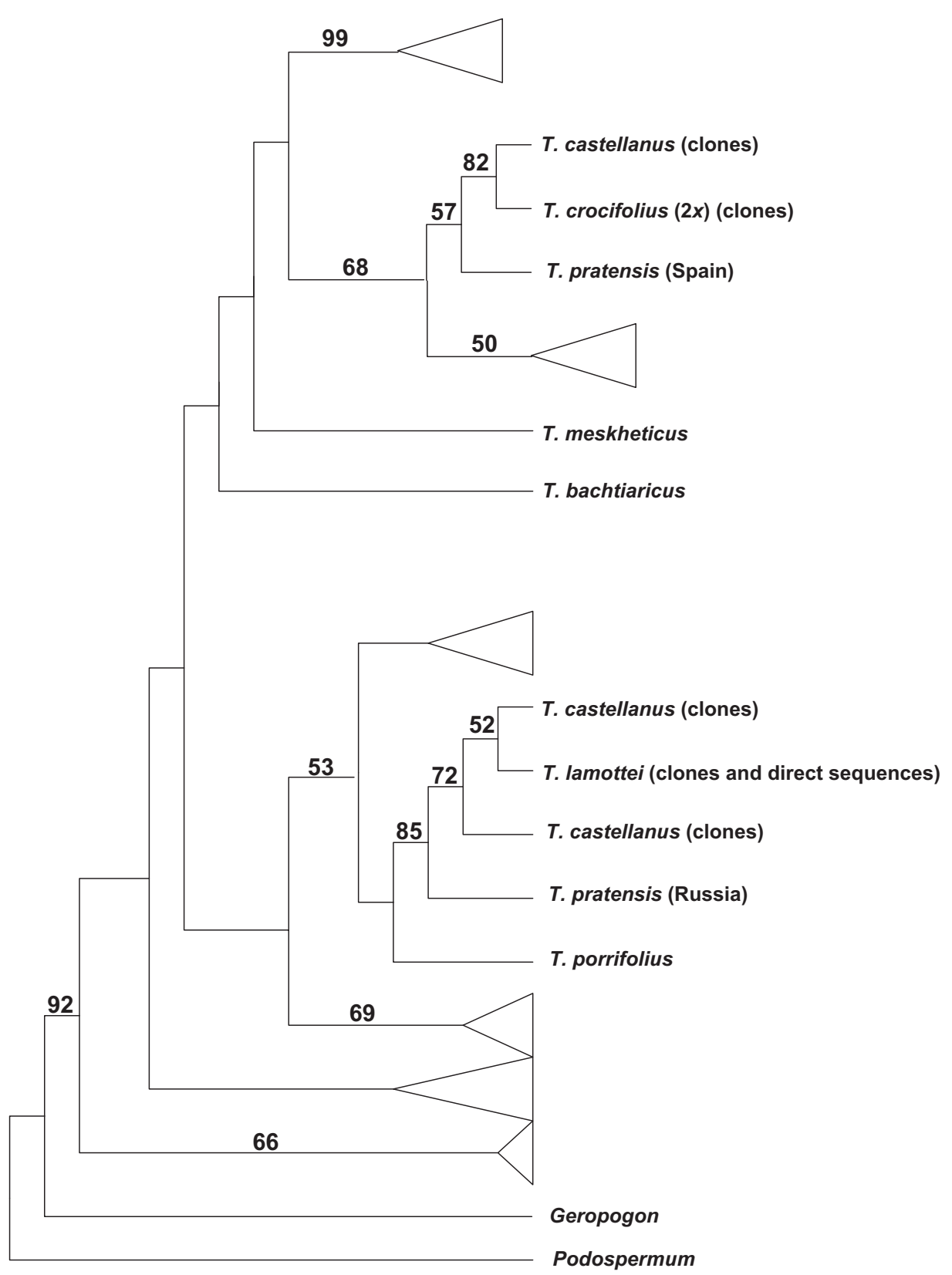

ITS (ML)

(b)

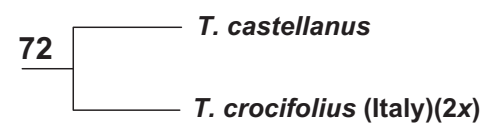

(c)

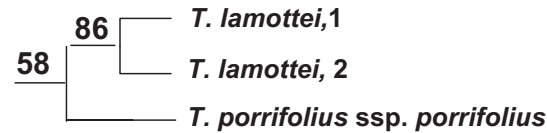

Fig. 1 (a) Simplified most probable topology recovered from a maximum likelihood $(M L)$ analysis of alcohol dehydrogenase $1 \mathrm{~A}$ gene (Adh) sequence data showing positions of clones and/or direct sequences of Tragopogon castellanus, T. crocifolius and T. lamottei. (b, c) Selected clades from most probable topology recovered from an ML analysis of internal transcribed spacers (ITS) one and two plus 5.8S ribosomal RNA gene (ITS) sequence data, showing positions of direct sequences of T. castellanus, T. crocifolius and T. lamottei. See Supporting Information Figs S1 and S2 for the details.

indel in Adh intron seven, positions 615-621 (Table S4). Furthermore, some were obtained from the same individual, 3627, which was from the type population of T. castellanus (Spain, province Burgos, Alar del Rey; ALAR), which possessed variants I and II. In the ML analysis, the T. crocifolius-like Adh copy was placed as sister to diploid T. crocifolius (82\% ML BS), and the
T. lamottei-like copy was placed in a clade together with T. lamottei and T.pratensis (Russia) (85\% ML BS) (Figs 1, S2; Table S4).

GenBank accession numbers for new sequence data used in this study are: Adh, KJ666771-KJ666877; rpl16, KJ666878KJ666961; ITS, KJ666962-KJ667046. 


\section{Chromosome analysis}

Mitotic FISH karyotyping was conducted on the diploids T. crocifolius and T. lamottei (Fig. 2). One FISH probe (18S rDNA) hybridized to the nucleolar organizing regions, that is, the $35 \mathrm{~S}$ rDNA arrays, and the other probes hybridized to Tragopogon tandem repeat sequences. The probes were applied as a mixture containing the $18 \mathrm{~S} \mathrm{rDNA}$, centromeric repeat (TPRMBO), subtelomeric repeat (TGP7) and interstitial repeat (TTR3) (Fig. 2). All four probes hybridized to the genomes of the Tragopogon taxa tested. To check FISH karyotyping of T. crocifolius, which lacked FISH signals on the three smallest chromosomes, the TTR15 probe was used. This probe was applied to chromosomes of T. crocifolius, the closely related T. pratensis (from Spain) (Fig. S3) and two T. castellanus individuals (Fig. S4).

GISH was applied to T.castellanus individuals from the T. lamottei-1 and T. lamottei-2 haplotype groups (Figs 3,4). All were found to be allotetraploids, with one subgenome predominantly hybridized by $T$. lamottei gDNA and the other subgenome predominantly hybridized by T.crocifolius gDNA. Two distinct $T$. castellanus karyotypes were observed, with one being a nonrecombined karyotype and the other having an intergenomic translocation (Figs 3,4).

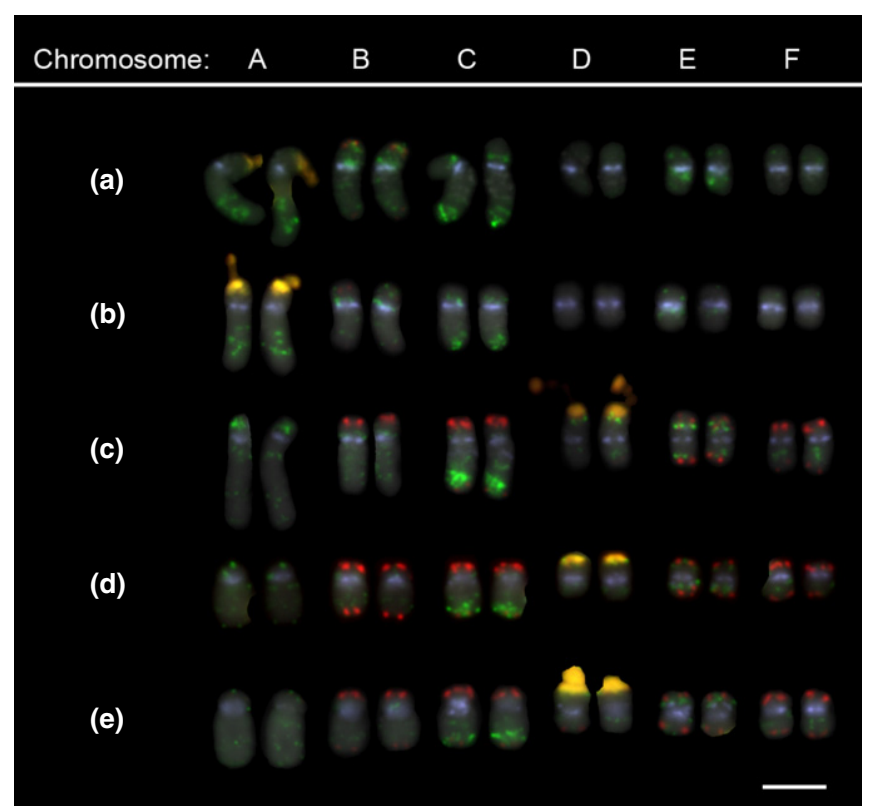

Fig. 2 Mitotic karyotypes of diploid progenitors of Tragopogon castellanus based on fluorescence in situ hybridization (FISH). (a, b) T. crocifolius and (c-e) T. lamottei. FISH probes were as follows: centromeric Tragopogon pratensis tandemly repetitive sequence $\mathrm{Mbol}$-rich (TPRMBO; lilac); subtelomeric Tragopogon porrifolius subtelomeric repeat-7 (TGP7; red); interstitial Tragopogon tandem repeat-3 (TTR3; green); and 18S rDNA (yellow/orange). Chromosomes, arranged by type (A-F), were counterstained with 4',6-diamidino-2-phenylindole (DAPI; grey). Parental accession numbers: (a) A-5; (b) A-4; (c) 3040-2/3576; (d) 3049-6/3582; and (e) 3031-19; see Supporting Information Table S1. Bar, $5 \mu \mathrm{m}$.
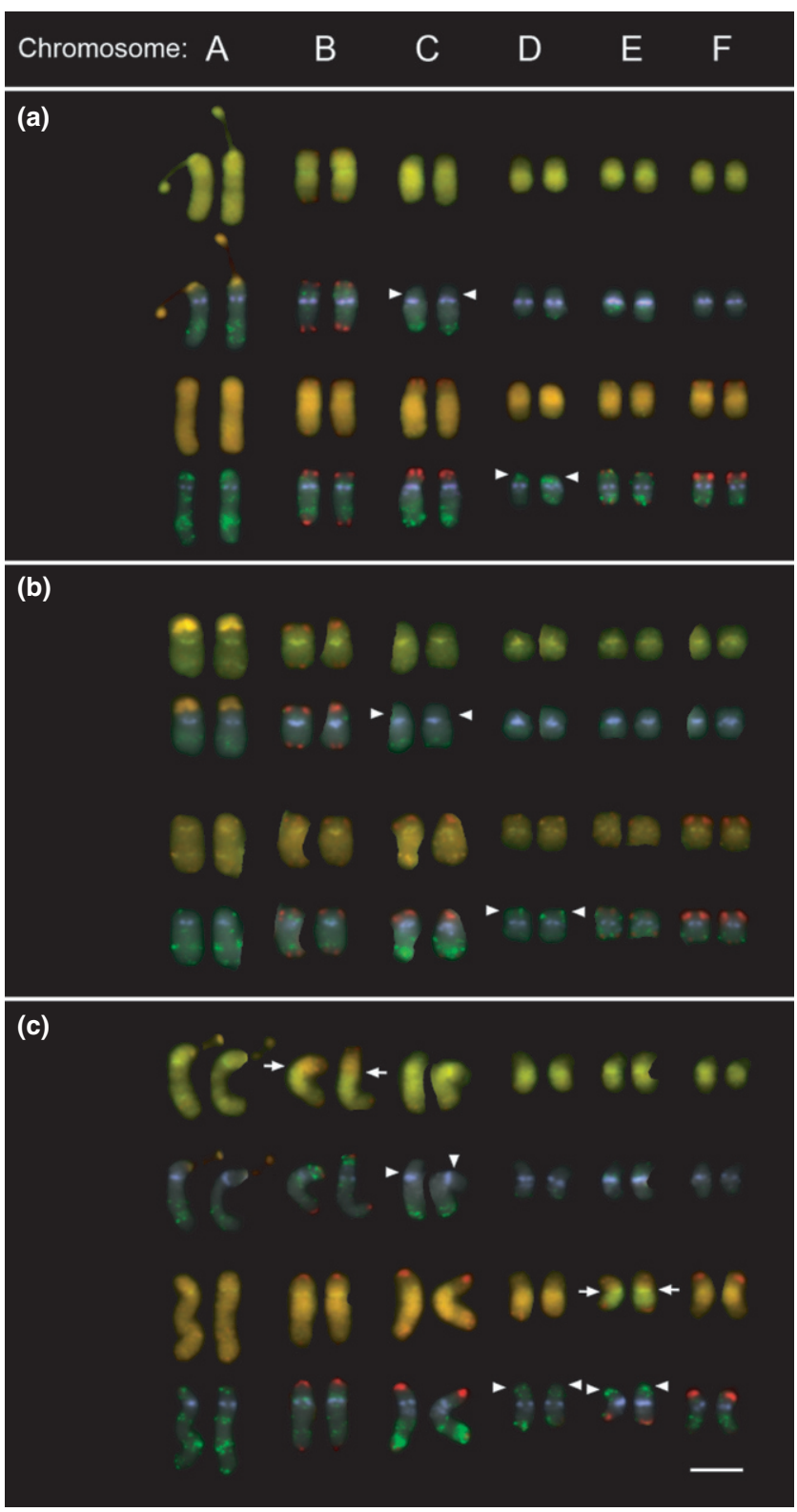

Fig. 3 Mitotic karyotypes of Tragopogon castellanus based on sequential fluorescence in situ hybridization (FISH) and genomic in situ hybridization $(\mathrm{GISH})$. Chromosomes, arranged by type (A-F), were counterstained with 4',6-diamidino-2-phenylindole (DAPI; grey) and are shown twice, with GISH signals and FISH signals, above and below, respectively. Karyotypes are shown for three individuals ( $T$. castellanus types A, B2 and B1 shown in $\mathrm{a}, \mathrm{b}$ and $\mathrm{c}$, respectively). Mitotic chromosomes were first subjected to FISH (above) and then to GISH (below). FISH probes were as follows:

centromeric $T$. pratensis tandemly repetitive sequence Mbol-rich (TPRMBO; lilac); subtelomeric T. porrifolius subtelomeric repeat-7 (TGP7; red); interstitial Tragopogon tandem repeat-3 (TTR3; green); and 18S rDNA (yellow/orange). GISH reprobing of the same chromosome preparations using total genomic DNA of $T$. crocifolius (green) and T. lamottei (red). Arrows indicate the positions of translocation breakpoints. Arrowheads indicate absent TTR3 signals compared with $T$. crocifolius. Parental accession numbers: (a) 3024-11/3537; (b) 3035-6/3552; and (c) 3053-2/ 3599. Bar, $5 \mu \mathrm{m}$. 

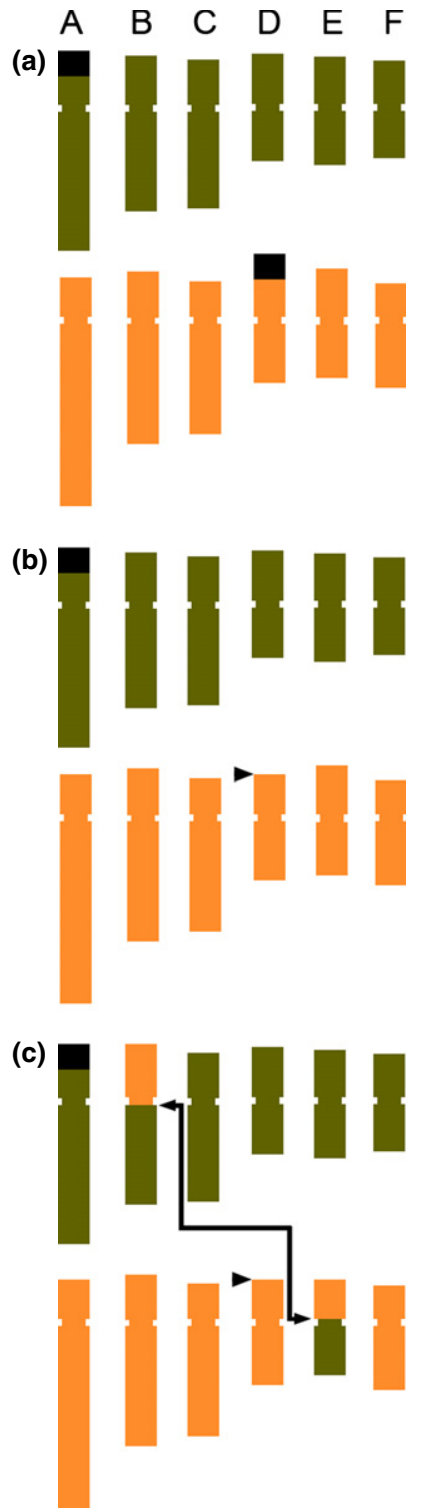

Fig. 4 Idiograms of Tragopogon castellanus. Hypothetical chromosome composition for an allotetraploid derived from T. crocifolius and T. lamottei shown in (a). Observed chromosome compositions are shown in (b) for T. castellanus types A and B2, and in (c) for T. castellanus type B1. Chromosomes are arranged by type (A-F) with colors indicating chromatin of $T$. crocifolius origin (green) and $T$. lamottei origin (orange). Blocks in black represent 35S rDNA sites. Arrowheads indicate the missing $35 \mathrm{~S}$ rDNA sites. Arrows indicate the position of translocation breakpoints.

All T. castellanus individuals with a T. lamottei-1 plastid haplotype were found to have a nonrecombined karyotype, and are referred to as 'type A' T. castellanus (Fig. 3a,b). By contrast, GISH revealed T.castellanus individuals with the T. lamottei-2 plastid haplotype to have either a nonrecombined karyotype ('B2', Fig. 3b) or a recombined karyotype B1 (Fig. 3c). All B1 individuals were observed to be morphologically different from B2 individuals (with B1 individuals appearing more like T. crocifolius), indicating a possible link between the chromosomal alteration and morphology.
FISH and GISH reprobing was conducted to identify subgenomes and to compare repeat distributions in T. castellanus with those in T.lamottei and T.crocifolius. Most FISH signals in T. castellanus (A, B1, B2) matched those observed at the corresponding sites in the genomes of T. lamottei and T.crocifolius (Figs 2-4). One exception to parental additivity in all T. castellanus plants was the absence of a $35 \mathrm{~S} \mathrm{rDNA}$ site in the T. lamottei subgenome that was expected to be present on the short arm of chromosome D. The other consistent difference was a TTR3 signal on the short arm of chromosome $\mathrm{C}$ from T. lamottei, which was present in the FISH-karyotyped T. crocifolius (Fig. 2), but absent in all T. castellanus (A, B1 and B2) (Figs 3, S4). FISH with TTR3 to the closely related Spanish T. pratensis (Mavrodiev etal., 2012; E. V. Mavrodiev etal., unpublished) showed a better match with regard to chromosome C, but exhibited differences on chromosome B (Fig. S3).

The intergenomic translocation characterizing type B1 T. castellanus appears to involve putatively nonhomeologous chromosomes, namely B from T.crocifolius and E from T. lamottei. Therefore, one chromosome of T. castellanus now comprises the long arms of $\mathrm{E}$ from T.crocifolius and $\mathrm{B}$ from T. lamottei, and the other comprises the reciprocal. However, the breakpoints in both chromosomes are in close proximity to the centromere (Fig. 3), and so the recombination event may have occurred between homologous centromeric sequences (e.g. TPRMBO). One other common change was that the short arm of $\mathrm{E}$ of T. lamottei origin lacked the subtelomeric repeat (TGP7) signals expected on the basis of T. lamottei karyotyping (Fig. 2).

\section{Geographical distributions}

Diploid T. crocifolius has been reported from France, Italy, Morocco and southwestern Spain (the single collection: Cordova, Carretera de Trassierra, río Guadalmellatillo, 5-V-1982, M. J. Díaez, I. Fernandez, SEV 90758) (e.g. Wilson, 1983; Vogt \& Oberprieler, 1993; Blanca \& Diaz De La Guardia, 1996). As a result of the wide polyphyly of T. crocifolius (Fig. S1; TableS5; Notes S1; see also Mavrodiev et al., 2008, 2012) and its unstable taxonomy, it is not clear which Spanish lineage of T.crocifolius was investigated by previous authors (reviewed in Blanca \& Diaz De La Guardia, 1996). During recent rounds of field collecting (2006 and 2012), we were unable to find or confirm diploid T. crocifolius in Spain.

The geographical distributions of T. lamottei and T. castellanus A, B1, B2 and C plants (Tables 1, S1) are summarized in Figs 5 and 6. B1 plants of T. castellanus, seven populations of T. castellanus $\mathrm{B} 2$ and the single population of T. castellanus $\mathrm{C}$ (Table S1) occur in the northern part of the Spanish province of Aragón (Fig. 5), in the central Pyrenees, in the vicinity in which most $T$. lamottei populations of the $T$. lamottei- 1 haplotype group occur (Figs 5, 6). By contrast, T. castellanus A populations, as well as the T. lamottei-2 haplotype group, occupy a different geographical area that mostly corresponds to the Cantabrian provinces of northern Spain (Navarra, La Rioja, northern and northeastern Castilla y León, south of Cantabria to southeastern Galicia), as well as the southern part of Aragón (Figs 5, 6). 
Table 1 General summary of results for ploidy levels, karyotypes, sequence comparisons and morphology of Tragopogon castellanus, T. crocifolius and T. lamottei

\begin{tabular}{|c|c|c|c|c|c|c|c|c|}
\hline Species & Parents/origins & Ploidy & Karyotype (FISH/GISH $\left.{ }^{1}\right)$ & Plastid (rp/16) & ITS & Adh & & Habit \\
\hline $\begin{array}{l}\text { T. crocifolius } \\
\text { (Italy, Sicily) }\end{array}$ & $\begin{array}{l}\text { Paternal parent } \\
\text { (origins } \mathrm{A} \text { and } \mathrm{B} \text { ) }\end{array}$ & $2 x$ & T. crocifolius & T. crocifolius & & T. crocifolius & & T. crocifolius \\
\hline T. castellanus & Origin A & $4 x$ & $\begin{array}{l}\text { c. (T. crocifolius + } \\
\text { T. lamottei) }\end{array}$ & T. lamottei, 1 & & & & T. castellanus \\
\hline T. castellanus & Origin B1 & $4 x$ & $\begin{array}{l}\text { c. }(\text { T. crocifolius }+ \\
\text { T. lamottei })\end{array}$ & $\begin{array}{l}\text { Similar to } \\
\text { T. lamottei, } 2\end{array}$ & T. crocifolius & $\begin{array}{l}\text { T. crocifolius - } \\
\text { Like clones }\end{array}$ & $\begin{array}{l}\text { T. lamottei- } \\
\text { Like clones }\end{array}$ & T. crocifolius \\
\hline T. castellanus & Origin B2 (presumable) & $4 x$ & $\begin{array}{l}\text { C. }(T . \text { crocifolius + } \\
\text { T. lamottei) }\end{array}$ & $\begin{array}{l}\text { Similar to } \\
\text { T. lamottei, } 2 \\
\text { T. lamottei, } 1\end{array}$ & & & & T. castellanus \\
\hline T. lamottei & $\begin{array}{l}\text { Maternal parent } \\
\text { (origins } A \text { and } B \text { ) }\end{array}$ & $2 x$ & T. lamottei & & T. lamottei & & T. lamottei & T. lamottei \\
\hline T. castellanus & $\begin{array}{l}\text { Origin } C \text { (reciprocal to } \\
\text { origins } A \text { and } B \text { ) }\end{array}$ & $4 x$ & No data & $\begin{array}{l}\text { T. lamottei, } 2 \\
\text { T. crocifolius }\end{array}$ & T. crocifolius & $\begin{array}{l}\text { T. crocifolius- } \\
\text { like clones }\end{array}$ & $\begin{array}{l}\text { T. lamottei- } \\
\text { like clones }\end{array}$ & T. crocifolius \\
\hline
\end{tabular}

Adh, alcohol dehydrogenase 1A gene; c., approximately; FISH, fluorescence in situ hybridization; GISH, genomic in situ hybridization; ITS, internal transcribed spacer.

\section{Discussion}

The origins of T. castellanus - evidence from molecular data and karyotyping

Sequence data in combination with the results of FISH and GISH confirmed that T. castellanus is derived from the diploid taxa T.crocifolius $(3606,3608,3609)$ and T.lamottei, as proposed earlier on the basis of more limited sampling of populations and genes (Mavrodiev et al., 2008), and that this polyploid formed at least three times. In two cases, T. lamottei was the maternal parent (Mavrodiev et al., 2008). Tragopogon crocifolius was the maternal parent only in the case of population CASTMON (Tables 1, S1; Fig. 5). This population represents a separate origin $(\mathrm{C})$ of $T$. castellanus and requires further investigation.

GISH and FISH also confirmed that T. castellanus is an allotetraploid. The cytogenetic data provide strong support for one parent being T. lamottei; the chromosomes of T. lamottei appear unchanged in T. castellanus, except for the loss of the parental $35 \mathrm{~S}$ rDNA locus. The other parent of the allotetraploid is most likely T.crocifolius, although one of the interstitial FISH signals was absent in $T$. castellanus compared with the T. crocifolius that was sampled. Possible explanations for the missing signal are that the exact parental genotype was not sampled, or that a loss or gain occurred following allotetraploid formation.

The ITS and Adh sequence data (Fig. 1; Tables S2, S4) are consistent with only a single origin of T. castellanus. By contrast, plastid sequence data suggest a minimum of three origins of T. castellanus (T. castellanus A, B and C) (Tables 1, S3).

Although distinguishable by karyotype and gross morphology, T. castellanus $\mathrm{B} 1$ and $\mathrm{B} 2$ could not be differentiated on the basis of the genetic markers used here. Therefore, the chromosomal rearrangements observed in T. castellanus B1 may have arisen following a single origin of B. Alternatively, B1 and B2 may represent independent origins, but the sequence data employed were unable to resolve them.

Our observations show that the chromosomes of the allotetraploids are still close to the sum of their parents in terms of content, except for the lost $35 \mathrm{~S}$ rDNA locus originating from T. lamottei. The chromosomal rearrangement in T. castellanus B1 appears to have arisen through a nonhomeologous intergenomic translocation. Therefore, as a result of the translocations being in a reciprocal state, the genetic contributions of the diploids are expected to be additive in these regions. Nonhomeologous translocations are much less common than homeologous translocations in young allopolyploid Tragopogon populations (T. mirus and T. miscellus) (Chester etal., 2012, Chester et al., 2014). The chromosomal alteration also raises the question as to whether it may provide a barrier to gene flow between type B1 vs A and B2 T. castellanus. No apparent hybrids were detected in T. castellanus that combined the B1 and B2 karyotypes. If the morphologically distinct $T$. castellanus $\mathrm{B} 1$ is consistently chromosomally distinct from A and B2, this might be another source of evidence for the recognition of $\mathrm{B} 1$ as a distinct species.

The intergenomic translocation in T. castellanus B1 presumably originated early after the origin of this allotetraploid type because it is fixed in multiple populations. Our results demonstrate that chromosomal novelty of the type observed shortly post-polyploidization in the recent allotetraploids T. mirus and T. miscellus (Chester etal. 2012; Chester etal., in press) can become fixed in a population.

\section{Taxonomy}

The taxonomy of the Spanish species of Tragopogon is extremely difficult even after comprehensive treatments (Diaz De La Guardia \& Blanca, 1988, 1990, 1992, 2004; Blanca \& Diaz De La Guardia, 1996; Blanca \& De la Guardia, 1997; Suarez-Santiago et al., 2011). For example, in the context of the present study, the 
Fig. 5 Distribution of Tragopogon castellanus. Map generated using ArcMap 10 and locality data for collections used in this study (Supporting Information Table S1).

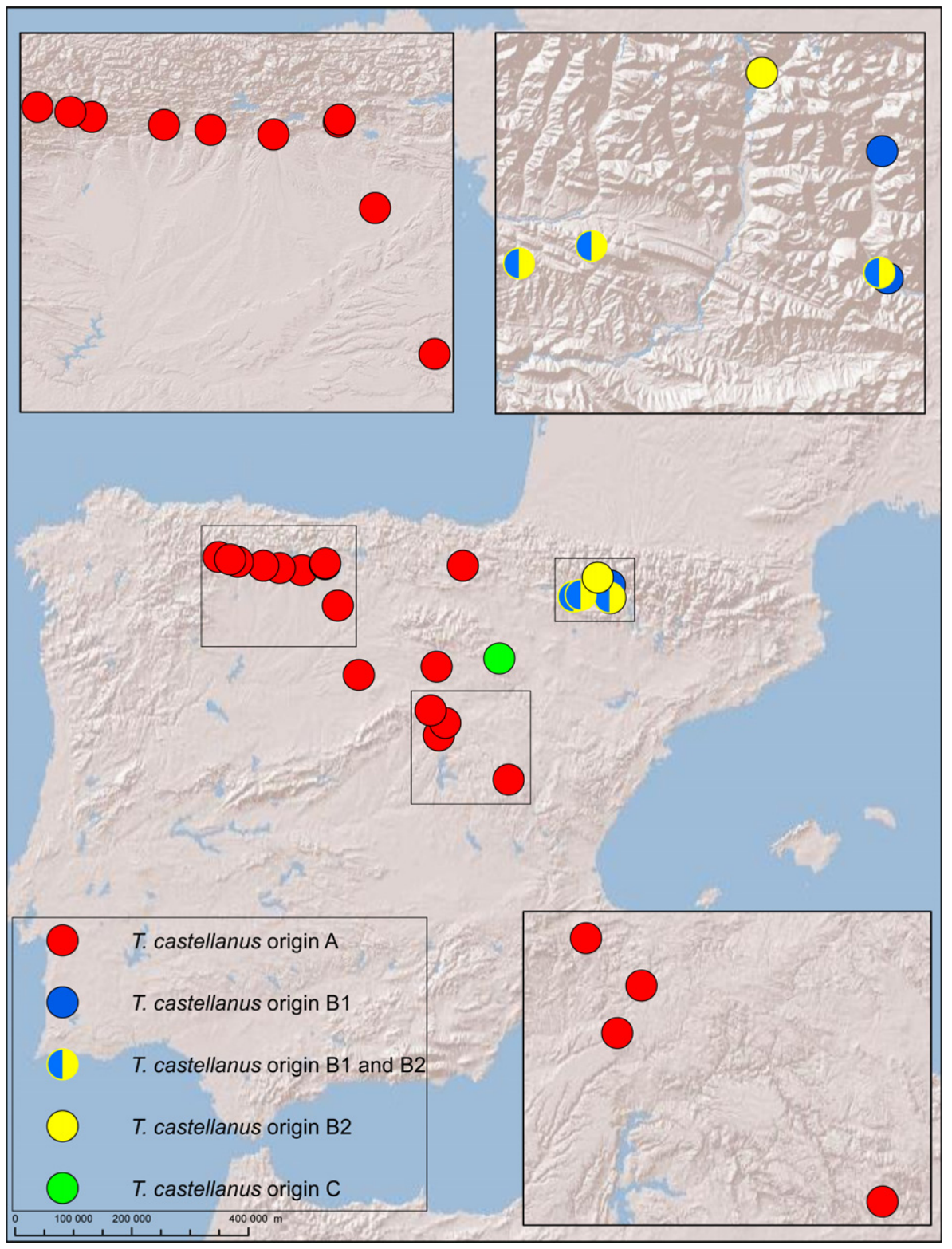

circumscription of the binomials 'T. bombycinus Gredilla', 'T. pratensis L.', 'T. villosus L.' or 'T. flaviflorus (Willk.) Willk.' still remains unclear (see also notes of Diaz De La Guardia \& Blanca (1992) and Blanca \& Diaz De La Guardia (1996) on T. villosus). This taxonomic uncertainty is partly understandable in the light of recent molecular studies showing that Tragopogon is a young, rapidly evolving genus (Bell et al., 2012; Mavrodiev etal., 2012) with hybridization and polyploidy adding to the complexity (e.g. Mavrodiev et al., 2008, 2012; Suarez-Santiago et al., 2011).

\section{Geographical distributions}

Based on herbarium records, initially we assumed that T. castellanus co-occurs with its two parents only in the Pyrenees. However, our data reveal that herbarium specimens identified as ' $T$. crocifolius' from this area are actually $T$. castellanus with a unique karyotype (B1) or unique plastid haplotype (origin C) (Fig. 5). Indeed, despite extensive fieldwork, we did not find T. crocifolius in Spain. Moreover, both T. castellanus B1 and B2 often co-occur in the Pyrenees with one parental species, T. lamottei (Figs 5, 6), but the T. lamottei sampled from the Pyrenees is not actually the genotype that contributed to the formation of T. castellanus B1 and B2 in that region - that parental genotype was restricted to northwestern Spain, genetically distinct and geographically well separated from plants in the Pyrenees (Fig. 6). Plants from the haplotype group T. lamottei-1 (the proposed maternal parent for T. castellanus origin A from Cantabria) are nearly absent in northern and northwestern Spain outside of Aragón. Hence, the allotetraploids are not growing in close proximity to the proposed maternal genotypes from which they appear to have been formed (reviewed in Juzepczuk, 1939; Stebbins, 1950). This picture is generally different from that which is observed in the northwestern USA, where the parental 


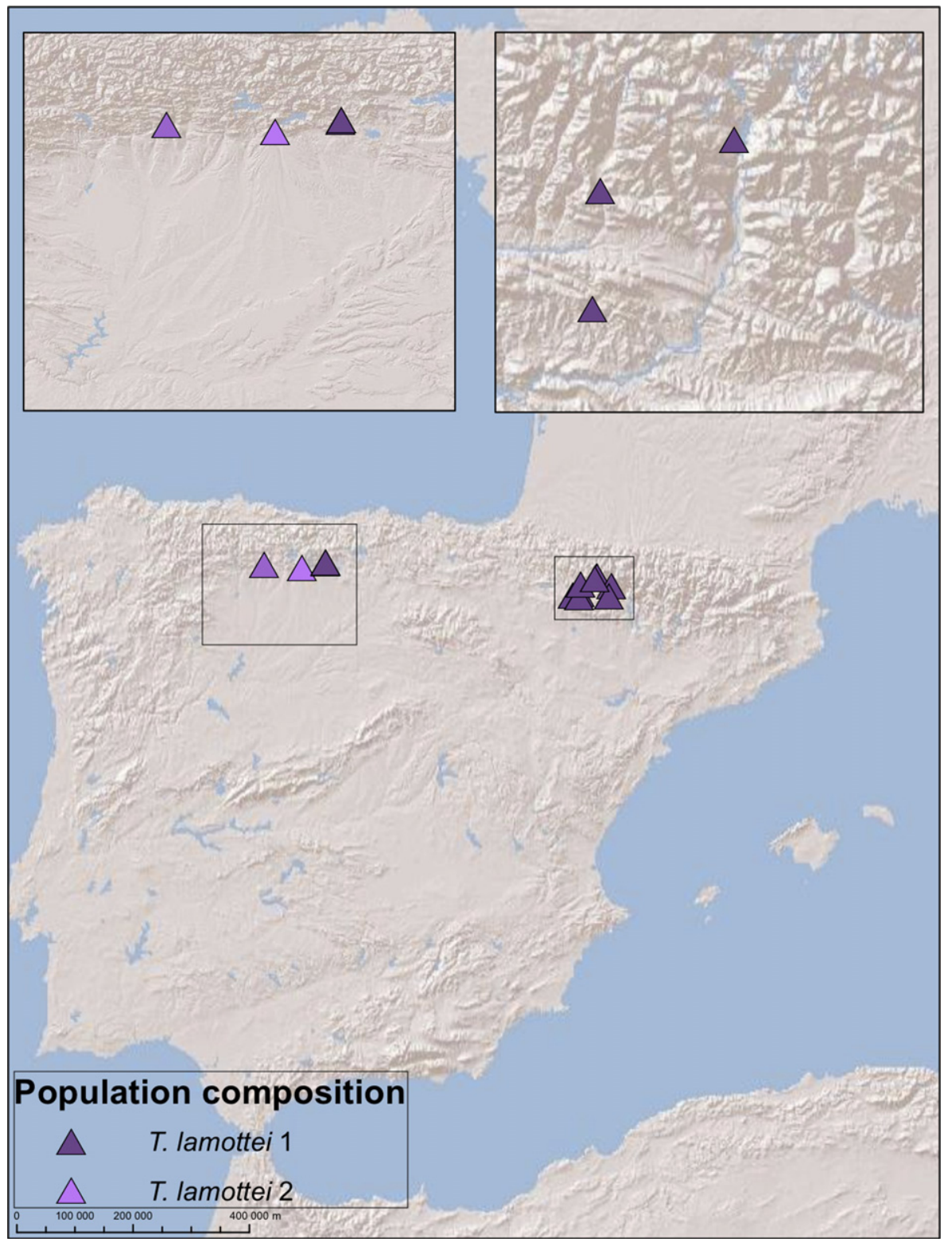

Fig. 6 Distribution of Tragopogon lamottei. Map generated using ArcMap 10 and locality data for collections used in this study (Supporting Information Table S1). genotypes are often in the same area as their young allotetraploid derivatives (T. mirus and T. miscellus) (Soltis et al., 2012; but see Roose \& Gottlieb, 1976; Soltis \& Soltis, 1991). Together with the apparent absence of diploid T. crocifolius in northern Spain (or perhaps the whole Iberian Peninsula), these data indicate that T. castellanus did not form recently and what might appear to be a straightforward occurrence of parents and their polyploid derivative is actually much more complex. For example, rather than indicating a recent formation of $T$. castellanus in the Pyrenees, the data reveal that genotypes have migrated, perhaps even becoming extinct in Spain (T. crocifolius), producing a complex evolutionary mosaic (see Stebbins, 1950).

Tragopogon castellanus is likely to be older than the recently formed New World allotetraploids T.mirus and T.miscellus which are estimated to be $c .40$ generations old (e.g. Soltis \& Soltis, 1991; Soltis etal., 2012). However, the exact age of the
Spanish polyploid still remains unclear. Tragopogon castellanus may have originated before the Last Glacial Maximum (LGM), and therefore its present-day distribution, and the distribution of its parents, could be a result of demographic changes during the ice ages of the Quaternary period (the last 2.6 million yr; Webb \& Bartlein, 1992). The Iberian Peninsula was one of the most important Pleistocene glacial refugia in Europe, and it has been shown that several Iberian refugia existed for a range of flora and fauna (cf. Gomez \& Lunt, 2006; Garcia-Jacas et al., 2009; Nieto Feliner, 2011). The internal complexity of the Iberian Peninsula as a glacial refugium could have supported a high degree of genetic diversity for many species throughout the Pleistocene. Various migrations caused by glaciation, for example, Centaurea (Suarez-Santiago etal., 2007; Garcia-Jacas et al., 2009) and Armeria (Fuertes Aguilar et al., 2011), together with the in situ survival of populations in microrefugia, could explain the genetic 
complexity observed for T. castellanus and it parents. The timeframe proposed here for Tragopogon in Spain agrees with that proposed for Centaurea (Barres et al., 2013).

\section{Conclusions}

Tragopogon crocifolius and the Iberian endemic, T. lamottei, are the parents of T.castellanus, which has formed at least three times. One morphologically distinct group of populations is differentiated from other T.castellanus in exhibiting two pairs of rearranged chromosomes, suggesting that some of the chromosomal variants that originate in young polyploids (here, an intergenomic translocation) may become fixed in populations, contributing to novelty in older polyploid lineages. The geographical distributions of T. castellanus and its parental taxa are complex, with allotetraploid populations being disjunct from one or both of the most similar diploid parental populations.

\section{Acknowledgements}

This work was supported by US National Science Foundation Grant DEB-1146065. Dr V. N. Suárez-Santiago was funded by a postdoctoral grant from the Spanish Ministry of Education and Science. Clayton J. Visger was funded by US NSF-DGE1315138. We thank Drs C. Diaz de la Guardia and G. Blanca for their suggestions and review of field collections. We thank three anonymous reviewers, and particularly reviewer 2 , for various helpful suggestions.

\section{References}

Barres L, Sanmartin I, Anderson CL, Susanna A, Buerki S, Galbany-Casals M, Vilatersana R. 2013. Reconstructing the evolution and biogeographic history of tribe Cardueae (Compositae). American Journal of Botany 100: 867-882.

Bell CD, Mavrodiev EV, Soltis PS, Calaminus AK, Albach DC, Cellinese N, Garcia-Jacas N, Soltis DE. 2012. Rapid diversification of Tragopogon and ecological associates in Eurasia. Journal of Evolutionary Biology 25: 24702480 .

Blanca G, De la Guardia CD. 1997. Fruit morphology in Tragopogon L. (Compositae: Lactuceae) from the Iberian Peninsula. Botanical Journal of the Linnean Society 125: 319-329.

Blanca G, Diaz De La Guardia C. 1996. Synopsis of the genus Tragopogon L. (Asteraceae) in the Iberian Peninsula. Anales del Jardín Botánico de Madrid54: 358-363.

Chester M, Gallagher JP, Symonds VV, da Silva AVC, Mavrodiev EV, Leitch AR, Soltis PS, Soltis DE. 2012. Extensive chromosomal variation in a recently formed natural allopolyploid species, Tragopogon miscellus (Asteraceae). Proceedings of the National Academy of Sciences, USA 109: 1176-1181.

Chester M, Lipman MJ, Gallagher JP, Soltis PS, Soltis DE. 2013. An assessment of karyotype restructuring in the neoallotetraploid Tragopogon miscellus (Asteraceae). Chromosome Research 21: 75-85.

Chester M, Riley RK, Soltis PS, Soltis DE. 2014. Patterns of chromosomal variation in natural populations of the neoallotetraploid Tragopogon mirus (Asteraceae). Heredity. doi:10.1038/hdy.2014.101.

Darlington CD, La Cour LF. 1969. The handling of chromosomes, 5th edn. London, UK: George Allen \& Unwin Ltd.

Diaz De La Guardia C, Blanca G. 1988. A little known species of Tragopogon L. (Compositae), T. lamottei Rouy. Lagascalia 15(Suppl.): 355-360.
Diaz De La Guardia C, Blanca G. 1990. Tragopogon castellanus Levier equals T. crocifolius ssp. badalii Willk. Anales del Jardín Botánico de Madrid (1979) 47: 253-256.

Diaz De La Guardia C, Blanca G. 1992. Lectotypification of five Linnaean species of Tragopogon L. (Compositae). Taxon 41: 548-551.

Diaz De La Guardia C, Blanca G. 2004. A new Spanish species of Tragopogon (Asteraceae: Lactuceae). Botanical Journal of the Linnean Society 146: 505-511.

Doyle JJ, Doyle JL. 1987. A rapid DNA isolation procedure for small quantities of fresh leaf tissue. Phytochemical Bulletin 19: 11-15.

Fuertes Aguilar J, Gutierrez Larena B, Nieto Feliner G. 2011. Genetic and morphological diversity in Armeria (Plumbaginaceae) is shaped by glacial cycles in Mediterranean refugia. Anales del Jardín Botánico de Madrid (1979) 68: 175-197.

Garcia-Jacas N, Soltis PS, Font M, Soltis DE, Vilatersana R, Susanna A. 2009. The polyploid series of Centaurea toletana: glacial migrations and introgression revealed by nrDNA and cpDNA sequence analyses. Molecular Phylogenetics and Evolution 52: 377-394.

Gomez A, Lunt DH. 2006. Refugia within refugia: patterns of phylogeographic concordance in the Iberian Peninsula. In: Weiss S, Ferrand N, eds. Phylogeography of southern European refugia. Dordrecht, the Netherlands: Springer, 155-188.

Hanson L, Boyd A, Johnson MAT, Bennett MD. 2005. First nuclear DNA C-values for 18 eudicot families. Annals of Botany 96: 1315-1320.

Juzepczuk SV. 1939. The problem of the species in the light of Darwin's doctrine. A report read to Darwin's seminary at the Botanical Institute of Academy of Science on April 8, 1939. Sovetskaya Botanika: 12-34.

Kato A, Lamb JC, Albert PS, Danilova T, Han F, Gao Z, Findley S, Birchler JA. 2011. Chromosome painting for plant biotechnology. In: Birchler JA, ed. Plant chromosome engineering: methods and protocols, methods in molecular biology. New York, NY, USA: Humana Press, 67-96.

Leresche LFJR, Levier E. 1881. Deux excursions botaniques dans le nord de l'Espagne et le Portugal en 1878 et 1879. Lausanne, Switzerland: Imprimerie Georges Bridel.

Mavrodiev EV, Gitzendanner M, Calaminus AK, Baldini RM, Soltis PS, Soltis DE. 2012. Molecular phylogeny of Tragopogon L. (Asteraceae) based on seven nuclear loci (Adh, GapC, LFY, AP3, PI, ITS, and ETS). Webbia 67: 111-137.

Mavrodiev EV, Soltis PS, Soltis DE. 2008. Putative parentage of six Old World polyploids in Tragopogon L. (Asteraceae: Scorzonerinae) based on ITS, ETS, and plastid sequence data. Taxon 57: 1215-1232.

Nieto Feliner G. 2011. Southern European glacial refugia: a tale of tales. Taxon 60: 365-372.

Pires JC, Lim KY, Kovarik A, Matyasek R, Boyd A, Leitch AR, Leitch IJ, Bennett MD, Soltis PS, Soltis DE. 2004. Molecular cytogenetic analysis of recently evolved Tragopogon (Asteraceae) allopolyploids reveals a karyotype that is additive of the diploid progenitors. American Journal of Botany 91: 1022-1035.

Richardson IBK. 1976. Tragopogon L. In: Tutin TG, Heywood VH, Burges NA, Moore DM, Valentine DH, Walters SM, Webb DA, eds. Flora Europaea. Cambridge, UK: Cambridge University Press, 322-326.

Roberts AV, Gladis T, Brumme H. 2009. DNA amounts of roses (Rosa L.) and their use in attributing ploidy levels. Plant Cell Reports 28: 61-71.

Roose ML, Gottlieb LD. 1976. Genetic and biochemical consequences of polyploidy in Tragopogon. Evolution 30: 818-830.

Soltis DE, Buggs RJA, Barbazuk WB, Chamala S, Chester M, Gallagher JP, Schnable PS, Soltis PS. 2012. The early stages of polyploidy: rapid and repeated evolution in Tragopogon. In: Soltis PS, Soltis DE, eds. Polyploidy and genome evolution. Heidelberg, Germany: Springer, 271-292.

Soltis PS, Soltis DE. 1991. Multiple origins of the allotetraploid Tragopogon mirus (Compositae) - rDNA evidence. Systematic Botany 16: 407-413.

Stamatakis A. 2014. RAxML Version 8: a tool for phylogenetic analysis and post-analysis of large phylogenies. Bioinformatics 30: 1312-1313.

Stebbins CL Jr. 1950. Variation and evolution in plants. New York, NY, USA: Columbia University Press.

Suarez-Santiago VN, de la Guardia CD, Soltis DE, Soltis PS, Blanca G. 2011. Tragopogon lainzii, a new species of Tragopogon (Asteraceae) segregated from T. dubius: evidence from morphological and molecular data. Systematic Botany 36: 470-480.

Suarez-Santiago VN, Salinas MJ, Garcia-Jacas N, Soltis PS, Soltis DE, Blanca G. 2007. Reticulate evolution in the Acrolophus subgroup (Centaurea L., 
Compositae) from the western Mediterranean: origin and diversification of section Willkommia Blanca. Molecular Phylogenetics and Evolution 43: 156-172.

Vogt R, Oberprieler C. 1993. Chromosome numbers of North African phanerogams. I. Flora Mediterranea 3: 187-210.

Webb TI, Bartlein PJ. 1992. Global changes during the last 3 million years: climatic controls and biotic responses. Annual Review of Ecology and Systematics 23: 141-173.

Willkomm HM. 1893. Supplementum prodromi florae Hispanicae. Stuttgart, Germany: Koch, E.

Wilson FD. 1983. Karyotypes of Tragopogon (Compositae, Lactuceae). Brittonia 35: 341-350.

Yokoya K, Roberts AV, Mottley J, Lewis R, Brandham PE. 2000. Nuclear DNA amounts in roses. Annals of Botany 85: 557-561.

\section{Supporting Information}

Additional supporting information may be found in the online version of this article.

Fig. S1 Maximum likelihood (ML) tree resulting from the analysis of Tragopogon alcohol dehydrogenase 1A $(A d h)$ data matrix.

Fig. S2 Maximum likelihood (ML) tree resulting from the analysis of Tragopogon internal transcribed spacer (ITS) sequences.

Fig. S3 Mitotic karyotypes of the diploids Tragopogon pratensis and T. crocifolius based on fluorescence in situ hybridization (FISH).

Fig. S4 Mitotic karyotypes of Tragopogon castellanus based on sequential fluorescence in situ hybridization (FISH) and genomic in situ hybridization (GISH).
Notes S1 Additional herbarium collections of Tragopogon crocifolius included in the study.

Table S1 Detailed summary of field collections of Tragopogon castellanus, T.crocifolius and T.lamottei used in this study, including ID, population numbers/abbreviations, GPS coordinates, ploidy level and summary of sequence data

Table S2 Summary of internal transcribed spacer (ITS) sequence comparisons for Tragopogon castellanus, T.crocifolius and T. lamottei

Table S3 Summary of rpl16 sequence comparisons for Tragopogon castellanus, T. crocifolius and T. lamottei

Table S4 Summary of alcohol dehydrogenase 1A ( $A d h)$ sequence comparisons and cloning data for Tragopogon castellanus, T. crocifolius and T. lamottei

Table S5 Summary of internal transcribed spacer (ITS) sequence comparisons for all herbarium samples of Tragopogon crocifolius

Please note: Wiley Blackwell are not responsible for the content or functionality of any supporting information supplied by the authors. Any queries (other than missing material) should be directed to the New Phytologist Central Office. 